\title{
Cytogenetic study of heptapterids (Teleostei, Siluriformes) with particular respect to the Nemuroglanis subclade
}

\author{
Daniel Luis Zanella Kantek', Wellington Adriano Moreira Peres², \\ Orlando Moreira-Filho ${ }^{3}$
}

I Taiamã Ecological Station, Chico Mendes Biodiversity Conservation Institute, Mato Grosso, Brazil 2 Environmental Protection Area Meanders of the Araguaia river, Chico Mendes Biodiversity Conservation Institute, Mato Grosso, Brazil 3 Laboratory of Molecular Biodiversity and Cytogenetics, Department of Genetics and Evolution, Federal University of São Carlos, São Paulo, Brazil

Corresponding author: Daniel Luis Zanella Kantek(daniel_kantek@hotmail.com)

$\frac{\text { Academic editor: R. Noleto | Received 25 August 2014 | Accepted } 7 \text { November } 2014 \text { | Published } 5 \text { February } 2015}{\text { http://zoobank.org/6C02C43E-8F05-45E1-87EA-5F676F348AF2 }}$

Citation: Kantek DLZ, Peres WAM, Moreira-Filho O (2015) Cytogenetic study of heptapterids (Teleostei, Siluriformes) with particular respect to the Nemuroglanis subclade. Comparative Cytogenetics 9(1): 17-29. doi: 10.3897/CompCytogen. v9i1.8488

\begin{abstract}
The catfish family Heptapteridae (order Siluriformes) is endemic to the Neotropics and is one of the most common of the fish families in small bodies of water. Although over 200 species have been identified in this family, very few have been characterized cytogenetically. Here, we analyze the chromosome genomes of four species of Heptapteridae: Cetopsorhamdia iheringi (Schubart \& Gomes, 1959), 2n = 58, comprising 28 metacentric $(\mathrm{m})+26$ submetacentric $(\mathrm{sm})+4$ subtelomeric (st) chromosomes; Pimelodella vittata (Lütken, 1874), 2n = 46, comprising 16m + 22sm + 8st; Rhamdia prope quelen (Quoy \& Gaimard, 1824), $2 \mathrm{n}=58$ comprising $26 \mathrm{~m}+16 \mathrm{sm}+14 \mathrm{st}+2$ acrocentric; and Rhamdiopsis prope microcephala (Lütken, 1874), $2 n=56$, comprising $12 m+30 s m+14 s t$. The nucleolus organizer regions (NORs) were located in a single chromosome pair in all species. The two species that belonged to the subclade Nemuroglanis, $C$. iheringi and $R$. prope quelen, had a diploid chromosome number of 58 and an interstitial NOR adjacent to a $\mathrm{C}^{+}$block located on one of the larger chromosome pairs in the complement. Our results from conventional cytogenetic techniques in combination with FISH using $18 \mathrm{~S}$ and 5S rDNA probes corroborated the taxonomical hypothesis for the formation of the Nemuroglanis subclade.
\end{abstract}

\section{Keywords}

Siluriformes, Heptapteridae, chromosomes, $5 \mathrm{~S}$ and $18 \mathrm{~S}$ rDNA, cytotaxonomy

Copyright Daniel Luis Zanella Kantek et al. This is an open access article distributed under the terms of the Creative Commons Attribution License (CC BY 4.0), which permits unrestricted use, distribution, and reproduction in any medium, provided the original author and source are credited. 


\section{Introduction}

In recent years, various classification changes have led to the current taxonomic status of the catfish family Heptapteridae. Lundberg et al. (1991a, b) suggested the division of the family Pimelodidae into the subfamilies Pimelodinae, Pseudopimelodinae, and Rhamdiinae. Subsequently, on the basis of phylogenetic studies in the Siluriformes, Pinna (1998) elevated the subfamily Rhamdiinae to the level of a family, Rhamdiidae. Bockmann and Guazzelli (2003) later established the family Heptapteridae instead of Rhamdiidae; this family includes 24 genera and 189 valid species (Ferraris 2007) of small fish, commonly known as "bagres" or "mandis". These fish are characterized by a long adipose fin, three pairs of barbels, an elongated body, and a grayish body color. They are endemic to the Neotropics and have a wide distribution in the water courses of Central and South America, with many species distributed in areas of ichthyological endemism. They live on the bottom of small and medium rivers, at low to medium depths, and are usually solitary with nocturnal habits (Bockmann and Guazelli 2003).

Subclades of Rhamdiinae (= Heptapteridae) have been identified in phylogenetic analyses of morphological data (Ferraris 1988, Lundberg et al. 1991a, Bockmann 1994): Rhamdia (Bleeker, 1858) and Pimelodella (Eigenmann \& Eigenmann, 1888) are assigned to a basal group; while Cetopsorhamdia (Eigenmann \& Fisher, 1916) and Rhamdiopsis (Haseman, 1911) have been placed in the Nemuroglanis subclade.

The diploid chromosome number in the Heptapteridae varies from $2 \mathrm{n}=42$ in Imparfinis hollandi (Haseman, 1911) (Margarido and Moreira-Filho 2008) to $2 \mathrm{n}=58$ in many other species. The latter chromosome number is the most frequent and is also considered a plesiomorphic character (Swarça et al. 2007, Borba et al. 2011). The karyotypes of heptapterid species comprise mainly metacentric and submetacentric chromosomes (see below) suggesting that pericentric inversions were more frequent than centric fissions in the evolution of the family. Nucleolus organizer regions (NORs) are usually present on one chromosome pair, and may be terminal or interstitial. These data suggest that extensive chromosomal rearrangements were involved in speciation within this group (Swarca et al. 2007). The reduction in diploid number may have been produced by successive chromosome fusions with deletions and inversions, such as those responsible for NOR position variation among species. B chromosomes are present in some species and are considered to be of recent origin, and without phylogenetic implications (Borba et al. 2011).

The presence of an interstitial NOR, which is usually located on the largest chromosome pair of the complement and adjacent to a $\mathrm{C}^{+}$block, and the predominance of $2 \mathrm{n}=58$, are all cytogenetic characters strongly associated with the Nemuroglanis subclade (Kantek et al. 2009).

As there have been relatively few cytogenetic studies in the Heptapteridae, and because of the need to obtain further data to substantiate proposals on the cytotaxonomy of the family (Borba et al. 2011), the present study was undertaken to provide the first analysis, to our knowledge, of the karyotype of Pimelodella vittata (Lütken, 1874). We also used various cytological methods to analyze three other heptapterid species and compared the new data with those previously published to examine the cytotaxonomy of this family. 


\section{Material and methods}

Specimens of four heptapterid species were collected from the Minhocas stream (S20 31'55.2", W04602' $\left.42.1^{\prime \prime}\right)$, a tributary of the Piumhi river (Minas Gerais state): nine (seven males and two females) Cetopsorhamdia iheringi (Schubart \& Gomes, 1959) (MNRJ 31477); six (five males and one female) P. vittata (MNRJ 29330); 10 (five males, four females and one of an undetermined sex) Rhamdia prope quelen (Quoy \& Gaimard, 1824) (MNRJ 29329, MNRJ 29326); and 18 (eight males, seven females and three of undetermined sex) of Rhamdiopsis prope microcephala (Lütken, 1874) (MNRJ 29325).

Mitotic metaphase preparations were made as described by Bertollo et al. (1978). Chromosome morphologies were assigned using the arm size ratio criteria proposed by Levan et al. (1964). Heterochromatin was identified by C-banding (Sumner 1972) and NORs were detected by silver nitrate staining (Howell and Black 1980). Metaphase preparations analyzed after conventional staining (Giemsa) were also subjected to C-banding, allowing the assemblage of sequential karyotypes.

The $18 \mathrm{~S}$ and $5 \mathrm{~S}$ rDNA sites on the chromosomes were located by the fluorescence in situ hybridization (FISH) technique (Pinkel et al. 1986), with a stringency of 77\%, using probes obtained from Prochilodus argenteus (Agassis, 1829) (Hatanaka and Galetti Jr 2004) and Leporinus elongatus (Valenciennes, 1850) (Martins and Galetti Jr 2001), respectively. The two probes were labeled with 14-dATP-biotin through nick translation in accordance with the manufacturer's instructions (Bionick Labelling System, Invitrogen). Chromosomes were counterstained with DAPI $(0.2 \mathrm{mg} / \mathrm{ml})$ and analyzed using an Olympus BX50 epifluorescence microscope. Image-Pro Plus software (Media Cybernetics) was used for image capture.

\section{Results}

\section{Cetopsorhamdia iheringi}

Cells from all $C$. iheringi specimens had $2 \mathrm{n}=58$ and a karyotypic formula of 28 metacentric (m), 26 submetacentric (sm) and 4 subtelocentric (st) chromosomes (Fig. 1a), with no evidence of heteromorphic sex chromosomes.

Silver staining showed that the NOR was located interstitially on the short arm of pair 1, and formed a secondary constriction (Fig. 1a box). Constitutive heterochromatin was present in the pericentromeric regions of several chromosome pairs (Fig. 1b) in addition to visible $\mathrm{C}^{+}$blocks in the NOR-bearing pair (Fig. 1a, b).

FISH with the $18 \mathrm{~S}$ rDNA probe confirmed that the NOR was located interstitially on the short arm of pair 1 (Fig. 4a). FISH using the $5 \mathrm{~S}$ ribosomal probe revealed the existence of a large number of these sequences on the NOR-bearing chromosomes, covering a large part of the chromosomes above and below the $18 \mathrm{~S}$ ribosomal sites. There was synteny between the $18 \mathrm{~S}$ and $5 \mathrm{~S}$ rDNAs (Fig. 4b, c). 
a
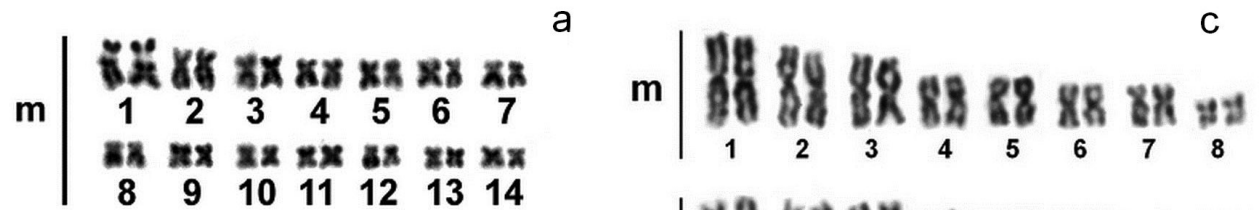

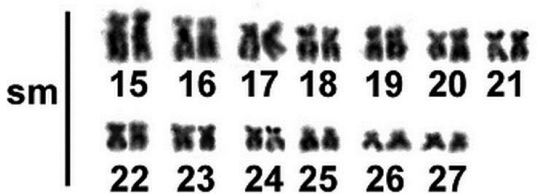
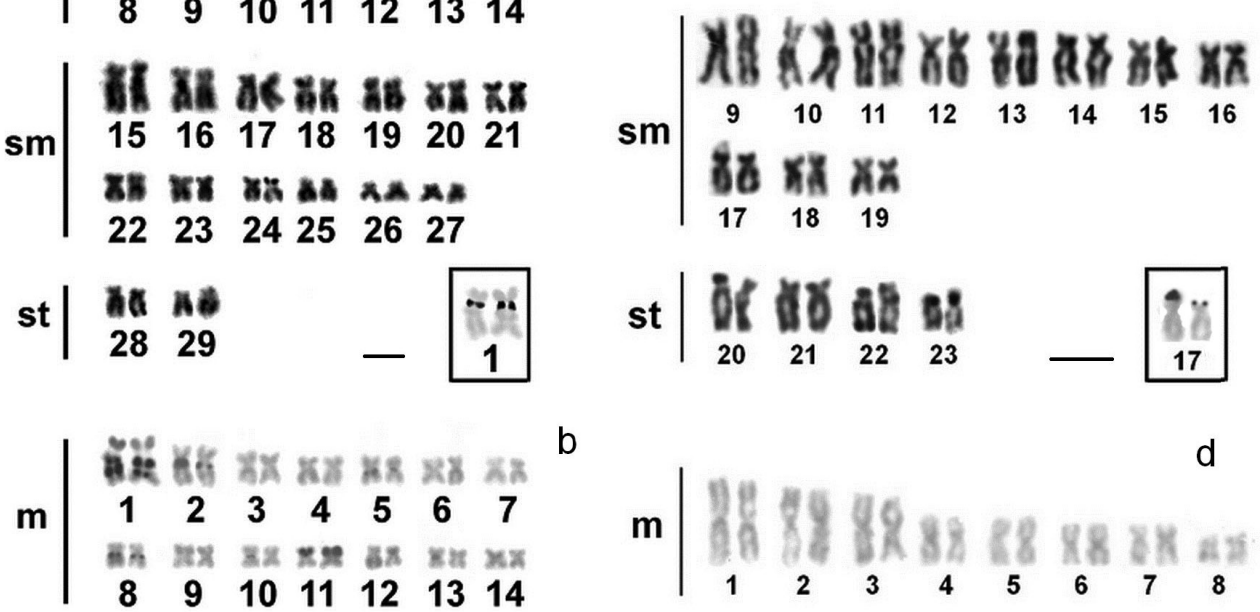

b
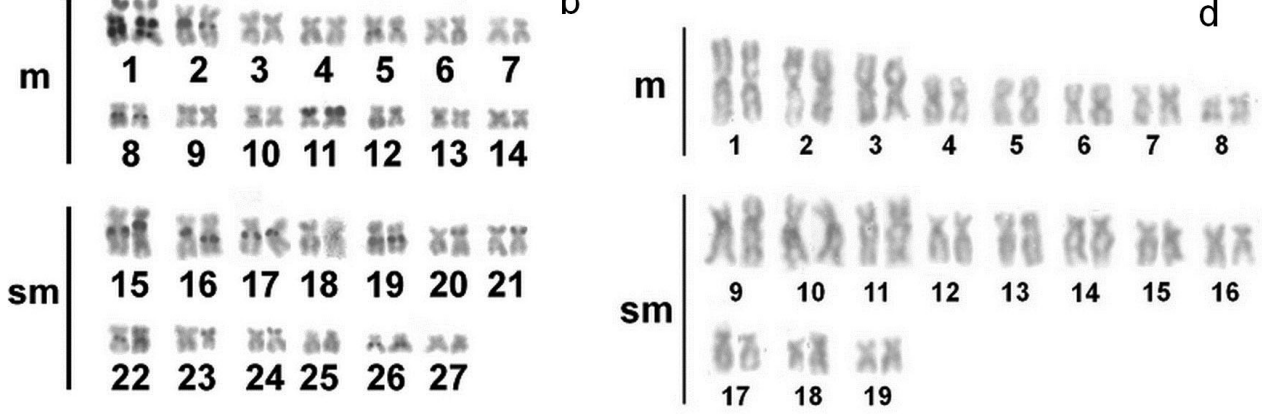

\begin{tabular}{l|ll} 
st & & \\
& $\mathbf{2 8}$ & $\mathbf{2 9}$
\end{tabular}

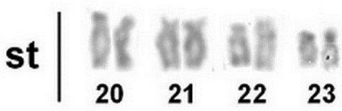

Figure I. Karyotypes of Cetopsorhamdia iheringi $(\mathbf{a}, \mathbf{b})$ and Pimelodella vittata $(\mathbf{c}, \mathbf{d})$ after sequential Giemsa staining $(\mathbf{a}, \mathbf{c})$, C- banding $(\mathbf{b}, \mathbf{d})$ and Ag-NOR staining (boxes). Bar $=10 \mu \mathrm{m}$.

\section{Pimelodella vittata}

All cells from P. vittata specimens had $2 \mathrm{n}=46$ and a karyotypic formula of $16 \mathrm{~m}, 22 \mathrm{sm}$ and 8st chromosomes (Fig. 1c), with no evidence of heteromorphic sex chromosomes.

Silver staining located the NORs to the terminal region of the short arm of pair 17, where they formed a secondary constriction (Fig. 1c box). It was possible to see weak $\mathrm{C}^{+}$bands close to the centromeres in some chromosomes (Fig. 1d).

FISH using the $18 \mathrm{~S}$ rDNA probe confirmed the NOR location (Fig. 4d). Only one $5 \mathrm{~S}$ rDNA locus was present in $P$. vittata in the terminal region of a submetacentric/subtelocentric chromosome pair (Fig. 4e). The $18 \mathrm{~S}$ and $5 \mathrm{~S}$ rDNA loci were not on the same pair of chromosomes (Fig. 4e, f). 


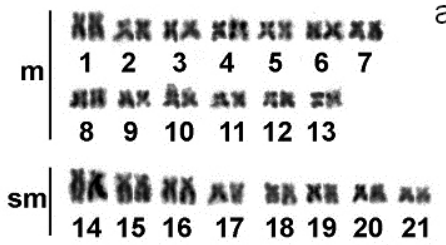

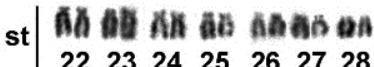

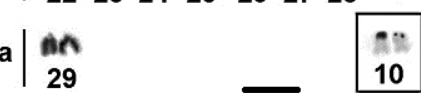

$\mathbf{m} \mid \begin{array}{ccccccc}1 & \mathbf{2} & \mathbf{3} & \mathbf{4} & \mathbf{5} & \mathbf{6} & \mathbf{7} \\ \mathbf{8} & \mathbf{9} & \mathbf{1 0} & \mathbf{1 1} & \mathbf{1 2} & \mathbf{1 3}\end{array}$

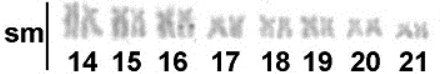

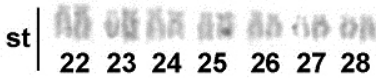

$\mathbf{a} \mid \begin{array}{ll}\text { fn } \\ \mathbf{2 9}\end{array}$

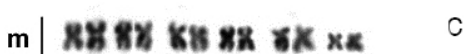

$\begin{array}{llllll}1 & 2 & 3 & 4 & 5 & 6\end{array}$

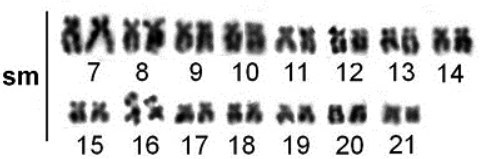

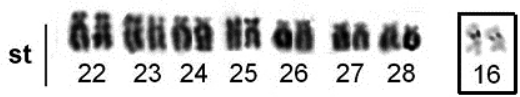

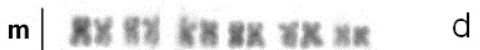
$\begin{array}{llllll}1 & 2 & 3 & 4 & 5 & 6\end{array}$

b

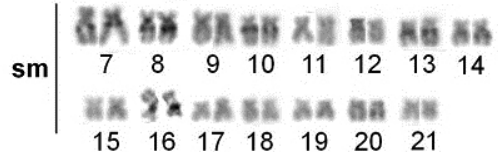

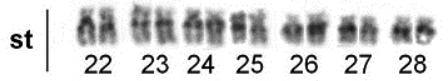

Figure 2. Karyotypes of Rhamdia prope quelen $(\mathbf{a}, \mathbf{b})$ and Rhamdiopsis prope microcephala (c, d) after sequential Giemsa staining (a, c), C- banding (b, d) and Ag-NOR staining (boxes). Bar $=10 \mu \mathrm{m}$.

\section{Rhamdia prope quelen}

Cells from all specimens, apart from one, had $2 \mathrm{n}=58$ and a karyotypic formula of $26 \mathrm{~m}, 16 \mathrm{sm}, 14 \mathrm{st}$ and 2 acrocentric chromosomes (Fig. 2a), with no evidence of heteromorphic sex chromosomes. One triploid specimen with $3 n=87$ was found (Fig. 3).

Silver staining indicated the NOR was located in the terminal region of chromosome pair 10, where it formed a secondary constriction (Fig. 2a box). The chromosomes did not show any heterochromatic segments (Fig. 2b).

FISH using the $18 \mathrm{~S} \mathrm{rDNA}$ probe hybridized to the same region as the Ag-NOR (Fig. 5a, c). Only one 5S rDNA locus was identified; this was located at an interstitial position on a submetacentric chromosome pair (Fig. 5b, d).

\section{Rhamdiopsis prope microcephala}

Cells from all specimens had $2 \mathrm{n}=56$ and a karyotypic formula of $12 \mathrm{~m}, 30 \mathrm{sm}$ and $14 \mathrm{st}$ chromosomes (Fig. 2c), with no evidence of heteromorphic sex chromosomes. 


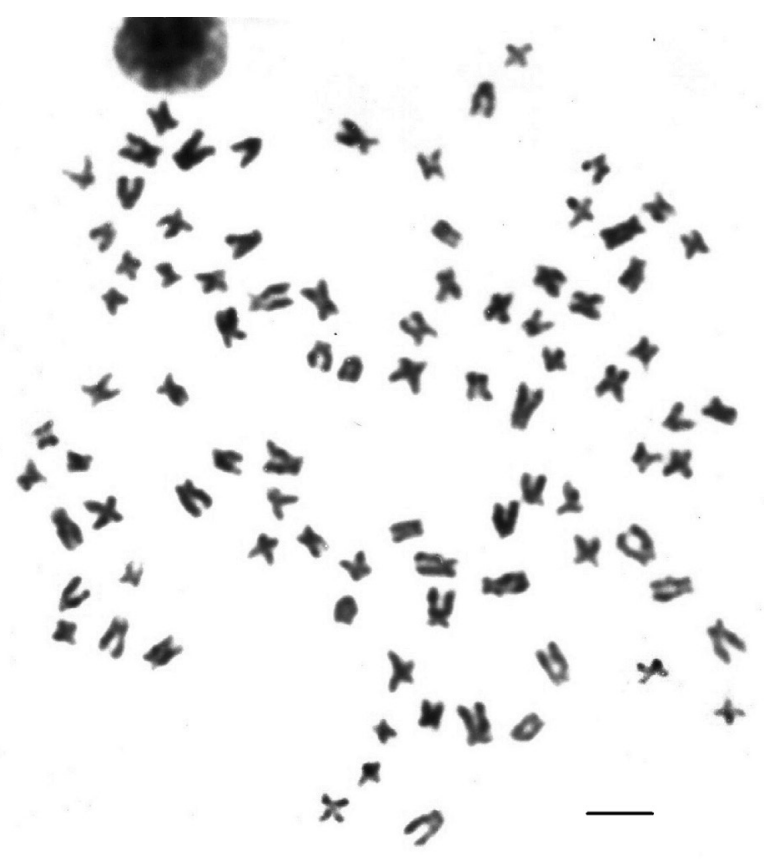

Figure 3. Metaphase of the triploid specimen of Rhamdia prope quelen. Bar $=10 \mu \mathrm{m}$.
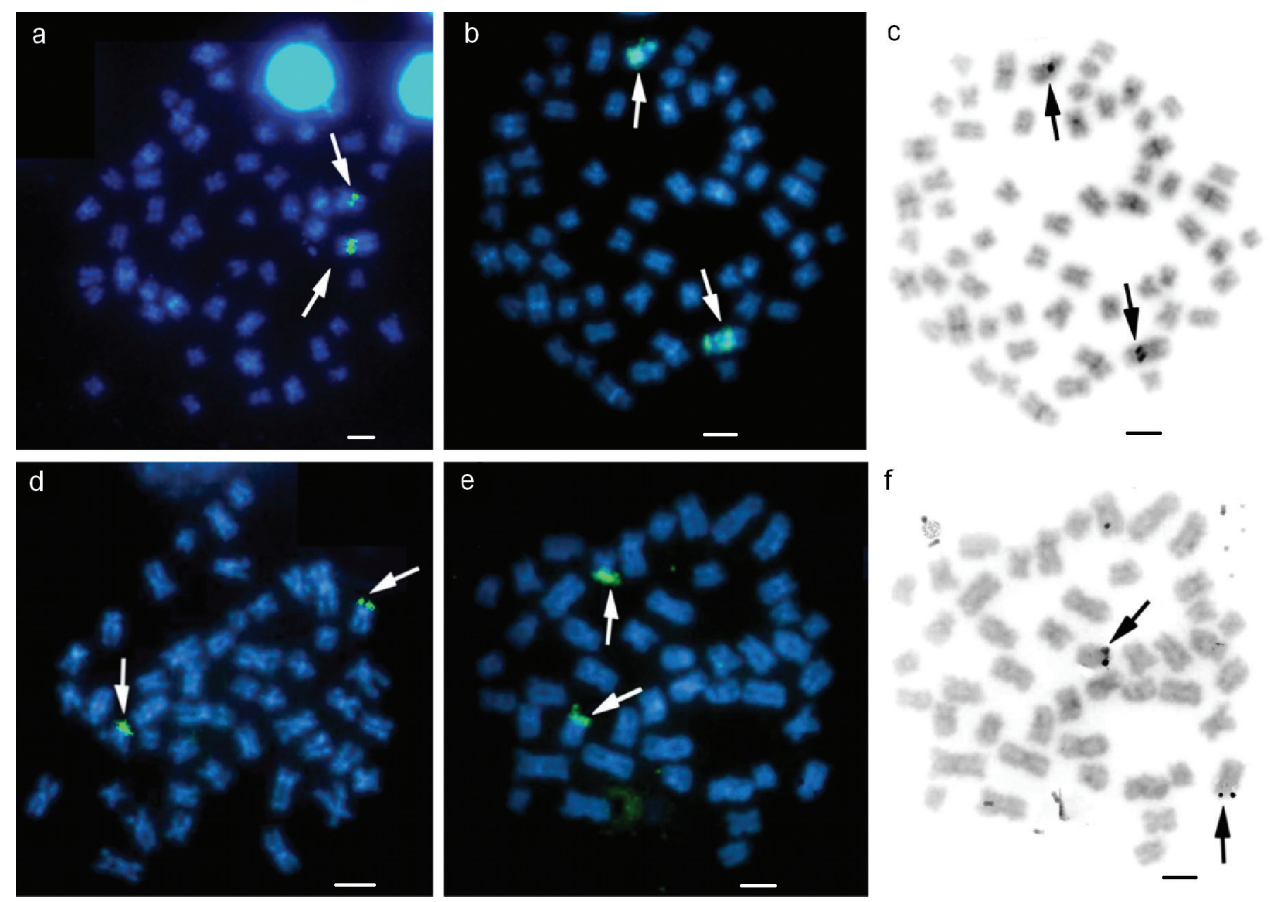

Figure 4. Metaphases of Cetopsorhamdia iheringi (a, b, c) and Pimelodella vittata (d, e, f) subjected to fluorescence in situ hybridization (FISH) with an $18 \mathrm{~S} \mathrm{rDNA}$ probe (a, d) and $5 \mathrm{~S} \mathrm{rDNA}(\mathbf{b}, \mathbf{e})$. The metaphases shown after Ag-NOR staining $(\mathbf{c}, \mathbf{f})$ are the same as those used for 5S FISH. Bar $=10 \mu \mathrm{m}$. 

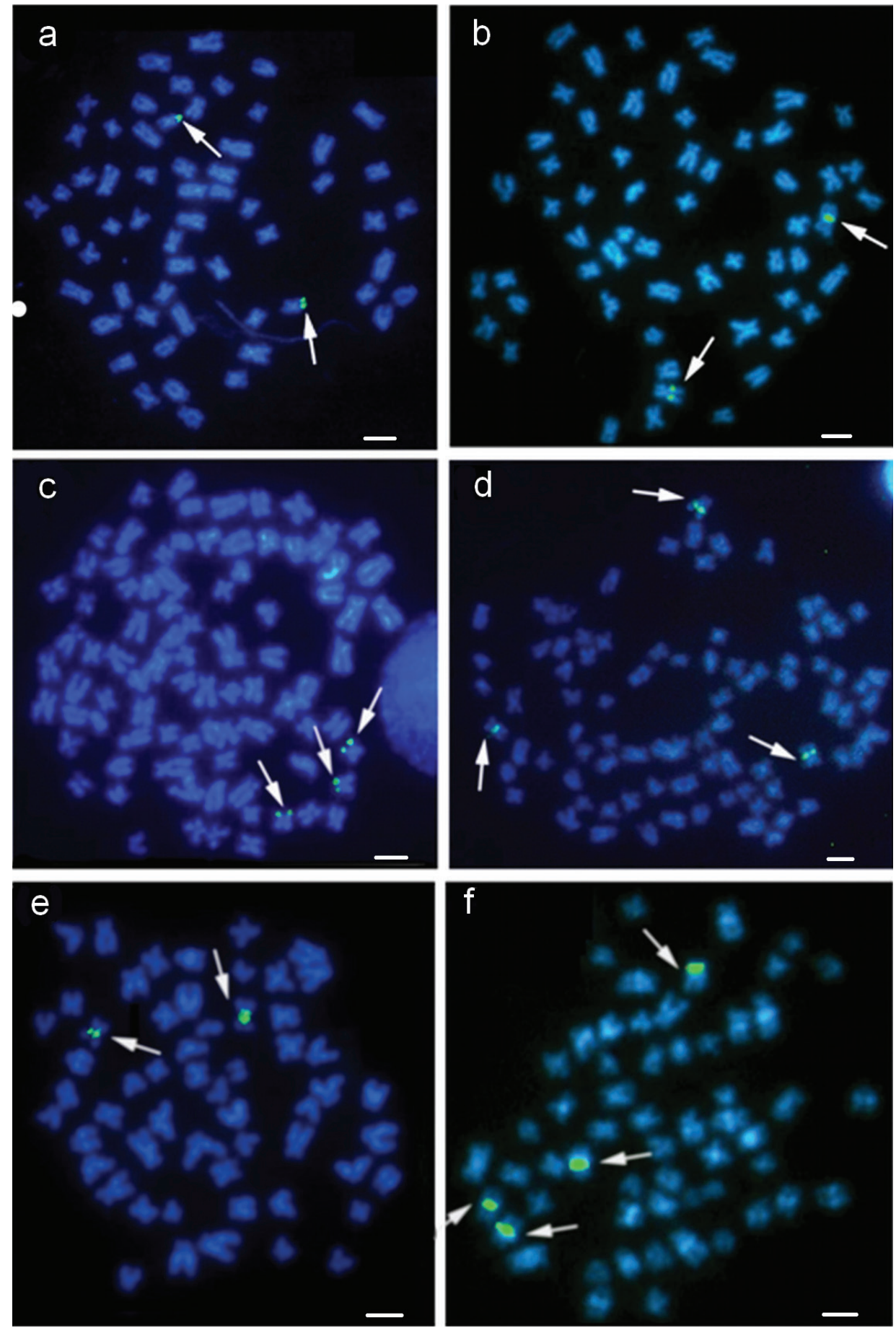

Figure 5. Metaphases of Rhamdia prope quelen $(\mathbf{a}, \mathbf{b}, \mathbf{c}, \mathbf{d})$ and Rhamdiopsis prope microcephala $(\mathbf{e}, \mathbf{f})$ subjected to fluorescence in situ hybridization with an $18 \mathrm{~S} \mathrm{rDNA}$ probe $(\mathbf{a}, \mathbf{c}, \mathbf{e})$ and $5 \mathrm{~S} \mathrm{rDNA}(\mathbf{b}, \mathbf{d}, \mathbf{f})$. Metaphases $\mathrm{c}$ and $\mathrm{d}$ belong to the triploid specimen. Bar $=10 \mu \mathrm{m}$. 
Silver staining indicated the NOR was located in an interstitial region of chromosome pair 16, where it formed a secondary constriction (Fig. 2c box). Constitutive heterochromatin was present in the pericentromeric regions of several chromosome pairs (Fig. 2d).

FISH using the $18 \mathrm{~S}$ rDNA probe hybridized to the same region as the Ag-NOR (Fig. 5e). Two $5 \mathrm{~S}$ rDNA loci were identified at a terminal position on a submetacentric/subtelocentric chromosome pair (Fig. 5f).

\section{Discussion}

The diploid chromosome number of 58 in $C$. iheringi and $R$. prope quelen is the most common karyotype number in the family Heptapteridae (Fenocchio and Bertollo 1990, Vissotto et al. 1999, Vissotto et al. 2001, Stolf et al. 2004, Kantek et al. 2009, Borba et al. 2011). The karyotype of $2 \mathrm{n}=46$ observed here in P. vittata is the same as reported for some other Pimelodella spp. (Dias and Foresti 1993, Vasconcelos and Martins-Santos 2000, Garcia and Almeida-Toledo 2010), P. avanhandavae (Eigenmann, 1917) (Vissoto et al. 1999), P. meeki (Eigenmann, 1910) (Vidotto et al. 2004, Garcia and Almeida-Toledo 2010, Borba et al. 2011, Gouveia et al. 2012), P. boschmai (Van der Stigchal, 1964) (Garcia and de Almeida-Toledo 2010) and P. gracilis (Valenciennes, 1836) (Garcia and de Almeida-Toledo 2010). Other Pimelodella species have different diploid chromosome numbers (Vasconcelos and Martins-Santos 2000, Swarça et al. 2003, Garcia and de Almeida-Toledo 2010).

The identification of a triploid specimen $(3 \mathrm{n}=87)$ in $R$. prope quelen is not unusual; indeed, three other cases have already been reported for Rhamdia (Swarça et al. 2007, Tsuda et al. 2010). The fertilization of a non-reduced (diploid) gamete by a reduced (haploid) gamete, such as an ovule (2n) by a sperm (n), is the most probable origin of these specimens (Morelli et al. 1983, Kantek et al. 2007).

The Nemuroglanis subclade is characterized by the presence of an interstitial NOR adjacent to a $\mathrm{C}^{+}$block and the predominance of $2 \mathrm{n}=58$; these characteristics are present in the analyzed species from the genus Cetopsorhamdia (Vissoto et al. 1999 and present study), Taunayia bifaciata (Eigenmann \& Norris, 1900) (Borba et al. 2011) and in five species of the genus Imparfinis (Eigenmann \& Norris, 1900) (Kantek et al. 2009, Borba et al. 2011, Gouveia et al. 2012). If $2 n=58$ is a plesiomorphic trait of the Heptapteridae family (Borba et al. 2011), then the reduction to $2 \mathrm{n}=56 \mathrm{might}$ indicate synapomorphy, grouping $I$. prope piperatus (Vissoto et al. 2001, Fenocchio et al. 2003), $R$. prope microcephala (present study) and $R$. microcephala (Lütken, 1874) (Fonseca et al. 2003). The hypothesis is supported by the presence of an interstitial NOR located on chromosomes that are not metacentric and not the largest in the karyotype of these species. The species Phenacorhamdia tenebrosa (Schubart, 1964), which belongs to the Nemuroglanis subclade, also has $2 \mathrm{n}=58$ (Borba et al. 2011), but no interstitial NOR. Since $2 \mathrm{n}=58$ is considered the basal number for Heptapteridae (Fenocchio et al. 2003, Borba et al. 2011), and the species Imparfinis borodini (Mees 
\& Cala, 1989) (Vissoto et al. 1999), I. hollandi (Margarido and Moreira-Filho 2008) and Heptapterus mustelinus (Valenciennes, 1835) (Yano and Margarido 2012) have a reduced diploid number $(2 \mathrm{n}=52,2 \mathrm{n}=42$ and $2 \mathrm{n}=54$, respectively), it is possible that Robertsonian translocations were responsible for the karyotypic changes.

The C-banding and Ag-NOR patterns of Rhamdia and Pimelodella species (Swarça et al. 2007, Borba et al. 2011, Gouveia et al. 2012) are distinctly different from most taxa of the Nemuroglanis subclade that have been analyzed. The existence of cytogenetic characteristics that separate the recognized groups of Heptapteridae was initially proposed by Fenocchio et al. (2003). Thus, for example, the interstitial $\mathrm{C}^{+}$band pattern is a more common feature of species of the Nemuroglanis subclade, such as $C$. iheringi and $R$. prope microcephala (Fig. $1 \mathrm{~b}, 2 \mathrm{~d}$, respectively). Other species of the family Heptapteridae that do not belong to this subclade, such as P. vittata (Fig. 1d) and $R$. prope quelen (Fig. 2b), have different patterns of heterochromatin distribution (Swarça et al. 2007, Garcia et al. 2010, Garcia and Almeida-Toledo 2010). However, as the majority of heptapterid species have not been studied cytogenetically studied, then it is difficult to elaborate broader proposals.

Another cytogenetic characteristic that may be diagnostic of the Nemuroglanis subclade is the synteny between $18 \mathrm{~S}$ and $5 \mathrm{~S}$ rDNA. Up until now, only Imparfinis schubarti (Gomes, 1956) (Kantek et al. 2009) and C. iheringi (present study) have been found to show this characteristic. Other genera in the Heptapteridae that do not belong to the Nemuroglanis subclade, such as Pimelodella and Rhamdia (Garcia et al. 2003, Garcia et al. 2010, present study), do not show this synteny. However, as $R$. prope microcephala did not have this characteristic, then the association between $5 \mathrm{~S}$ and $18 \mathrm{~S}$ rDNA might be a synapomorphy, shared by the group of species in the Nemuroglanis subclade that have a $2 \mathrm{n}=58$ karyotype and possess interstitial NORs on the largest chromosome pair of the complement.

The $5 \mathrm{~S}$ ribosomal gene consists of multiple copies of a highly conserved 150 base pair sequence, separated by highly variable non-transcribed spacers (Williams and Strobeck 1985). These variable sequences, which were caused by insertions/deletions, mini-repetitions and pseudogenes, are useful for evolutionary studies and serve as population markers for many organisms, including plants (Zanke et al. 1995), mammals (Suzuki et al. 1994) and fishes (Martins et al. 2002). Variations in these spacers have also been detected in some neotropical fishes, such as Leporinus (Martins and Galetti Jr 2001) and Brycon (Wasko et al. 2001). A comparison of the outcome of analysis of I. schubarti (Kantek et al. 2009) and C. iheringi indicates that despite the relative evolutionary proximity of the species (both belong to the Nemuroglanis clade), and the likely localization of these sequences to homeologous chromosomes, there is nevertheless considerable differences in the signals obtained with the $5 \mathrm{~S}$ rDNA probe. The large $5 \mathrm{~S}$ rDNA blocks on $C$. iheringi chromosomes presumably originated through duplication of the $5 \mathrm{~S}$ rDNA of an ancestral species close to these taxa. Other species of heptapterids considered more basal in the family, such as species belonging to the genera Rhamdia and Pimelodella, have only small $5 \mathrm{~S}$ rDNA signals; this suggests that the presence of the large $5 \mathrm{~S} \mathrm{rDNA}$ block in $C$. iheringi is an apomorphic character. Based on the supposed homogeneity among $5 \mathrm{~S}$ rDNA repeats, 
several studies have proposed that $5 \mathrm{~S}$ rDNA is subject to concerted evolution (Arnheim 1983), where duplicated gene family members evolve as a single unit that undergoes a high degree of homogenization (as a unit in concert) (Pinhal et al. 2011).

Prior to this study, variability in the number and location of $5 \mathrm{~S}$ ribosomal genes has been reported among Siluriformes (Kavalko et al. 2004) except for Rhamdia (Garcia et al. 2010). The analyses here confirm the variability observed by other authors, and also the conservation of $5 \mathrm{~S}$ rDNA in Rhamdia.

Until now, only the genera Imparfinis, Cetopsorhamdia, Heptapterus, Phenacorhamdia, Rhamdiopsis, Pimelodella, Rhamdia, and Taunayia had been cytogenetically analyzed; these represent only eight of the 24 genera in the family Heptapteridae (Yano and Margarido 2012). The first five belong to the subclade Nemuroglanis. More studies involving this family may assist in the elucidation of cytotaxonomy and chromosome evolution in this family.

\section{References}

Arnheim N (1983) Concerted evolution of multigene families. In: Nei M, Koehn RK (Eds) Evolution of genes and proteins. Sunderland, Sinauer, 38-61.

Bertollo LAC, Takahashi CS, Moreira-Filho O (1978) Cytotaxonomic consideration on Hoplias lacerdae (Pisces, Erythrinidae). Brazilian Journal of Genetics 1: 103-120.

Bockmann FA (1994) Description of Mastiglanis asopos, a new pimelodid catfish from northern Brazil, with comments on phylogenetic relationships inside the subfamily Rhamdiinae (Siluriformes: Pimelodidae). Proceedings of the Biologial Society of Washington 107: 760-777. doi: 10.1643/CI-04-019R1

Bockmann FA, Guazzeli GM (2003) Family Heptapteridae (Heptapterids). In: Reis RE, Kullander SO, Ferraris CJJr (Eds) Checklist of the Freshwater Fishes of South and Central America. Edipucrs, Porto Alegre, 406-431.

Borba RS, Silva EL, Pacheco ACS, Parisi-Maltempi PP, Alves AL (2011) Trends in the karyotypic evolution of the Neotropical catfish family Heptapteridae Bockmann 1998 (Teleostei: Siluriformes). Reviews in Fish Biology and Fisheries 22: 509-518. doi: 10.1007/ s11160-011-9245-3

Dias AL, Foresti F (1993) Cytogenetic studies on fishes of the family Pimelodidae (Siluroidei). Brazilian Journal of Genetics 16: 585-600. doi: 10.1590/S1415-47572000000300015

Fenocchio AS, Bertollo LAC (1990). Supernumerary chromosomes in a Rhamdia hilarii population (Pisces, Pimelodidae). Genetica 81: 193-198. doi: 10.1007/BF00360864

Fenocchio AS, Bertollo LAC, Takahashi CS, Dias AL, Swarça AC (2003) Cytogenetic studies and correlated considerations on Rhamdiinae relationships (Pisces, Siluroidei, Pimelodidae). Cytologia 68: 363-368. doi: 10.1508/cytologia.68.363

Ferraris Jr CJ (1988) Relationships of the neotropical catfish genus Nemuroglanis, with a description of a new species (Osteichthyes: Siluriformes: Pimelodidae). Proceedings of the Biologial Society of Washington 101: 509-516. 
Ferraris Jr CJ (2007) Checklist of catfishes, recent and fossil (Osteichthyes: Siluriformes), and catalogue of siluriform primary types. Zootaxa 1418: 1-628.

Fonseca YM, Oliveira C, Foresti F, Maistro EL (2003) First cytogenetic description of the species Rhamdela microcephala (Pisces, Heptapteridae). Cytologia 68: 31-34. doi: 10.1508/cytologia.68.31

Garcia C, Almeida-Toledo LF (2010) Comparative chromosomal analyses in species of the genus Pimelodella (Siluriformes, Heptapteridae): occurrence of structural and numerical polymorphisms. Caryologia 63: 32-40. doi: 10.1080/00087114.2010.10589706

Garcia C, Moreira-Filho O, Bertollo LAC, Centofante L (2003) B chromosomes and natural triploidy in Rhamdia sp. (Pisces, Siluriformes, Heptapteridae). Cytologia 68: 403-411. doi: $10.1508 /$ cytologia.68.403

Garcia C, Oliveira C, Almeida-Toledo LF (2010) Karyotypic evolution trends in Rhamdia quelen (Siluriformes, Heptapteridae) with considerations about the origin and differentiation of its supernumerary chromosomes. Genetics and Molecular Research 9: 365-384. doi: 10.4238/vol9-1gmr750

Gouveia JG, Moraes VPO, Sampaio TR, da Rosa R, Dias AL (2012) Considerations on karyotype evolution in the genera Imparfinis Eigenmann and Norris 1900 and Pimelodella Eigenmann and Eigenmann 1888 (Siluriformes: Heptapteridae). Reviews in Fish Biology and Fisheries 23: 215-227. doi: 10.1007/s11160-012-9286-2

Hatanaka TE, Galetti Jr PM (2004) Mapping of the 18S and 5S ribosomal RNA genes in the fish Prochilodus argenteus, Agassiz, 1829 (Characiformes, Prochilodontidae). Genetica 122: 239-244. doi: 10.1007/s10709-004-2039-y

Howell WM, Black DA (1980) Controlled silver staining of nucleolus organizer regions with a protective colloidal developer: a 1-step method. Experientia 36: 1014-1915. doi: 10.1007/ BF01953855

Kantek DLZ, Noleto RB, Fenocchio AS, Cestari MM (2007) Cytotaxonomy, heterochromatic polymorphism and natural triploidy of a species of Astyanax (Pisces, Characidae) endemic to the Iguaçu River Basin. Brazilian Archives of Biology and Technology 50: 67-74. doi: 10.1590/S1516-89132007000500007

Kantek DLZ, Peres WAM, Buckup PA, Moreira-Filho O (2009) Cytogenetics of Imparfinis schubarti (Siluriformes: Heptapteridae) from the Piumhi drainage, a diverted river in Minas Gerais State, Brazil. Zoologia 26: 733-738. doi: 10.1590/S1984-46702009000400018

Kavalco KF, Pazza R, Bertollo LAC, Moreira-Filho O (2004) Gene mapping of 5S rDNA sites in eight fish species from the Paraíba do Sul river Basin, Brazil. Cytogenetic and Genome Research 106: 107-110. doi: 10.1159/000078567

Levan A, Fredga K, Sandberg AA (1964) Nomenclature for centromeric position on chromosomes. Hereditas 52: 201-220. doi: 10.1111/j.1601-5223.1964.tb01953.x

Lundberg JG, Bornbush AH, Mago-Leccio F (1991a) Gladioglanis conquistador n. sp. from Ecuador with Diagnoses of the Subfamilies Rhamdiinae Bleeker and Pseudopimelodinae n. subf. (Siluriformes: Pimelodidae). Copeia 1: 190-209. doi: 10.2307/1446263

Lundberg JG, Mago-Leccio F, Nass P (1991b) Exallondontus aguanai, a new genus and species of Pimelodidae (Pisces, Siluriformes) from the deep river channels of South America, 
and delimitation of the subfamily Pimelodidae. Proceedings of The Biological Society of Washington 104: 840-869.

Margarido VP, Moreira-Filho O (2008) Karyotypic differentiation through chromosome fusion and number reduction in Imparfinis hollandi (Ostariophysi, Heptapteridae). Genetics and Molecular Biology 31: 235-238. doi: 10.1590/S1415-47572008000200012

Martins C, Galetti Jr PM (2001) Organization of 5S rDNA in species of the fish Leporinus: two different genomic locations are characterized by distinct nontranscribed spacers. Genome 44: 903-910. doi: 10.1139/gen-44-5-903

Martins C, Wasko AP, Oliveira C, Porto-Foresti F, Parise-Maltempi PP, Wright JM, Foresti F (2002) Dynamics of 5S rDNA in the tilapia (Oreochromis niloticus) genome: Repeat units, enverted sequences, pseudogenes and chromosome loci. Cytogenetic and Genome Research 98: 78-85. doi: 10.1159/000068542

Morelli S, Bertollo LAC, Moreira-Filho O (1983) Cytogenetic considerations on the genus Astyanax (Pisces, Characidae) II. Occurrence of natural triploidy. Caryologia 36: 245-250. doi: 10.1080/00087114.1983.10797665

Pinhal D, Yoshimura TS, Araki CS, Martins C (2011) The 5S rDNA family evolves through concerted and birth-and-death evolution in fish genomes: an example from freshwater stingrays. BMC Evolutionary Biology 11: 151. doi: 10.1186/1471-2148-11-151

Pinkel D, Straume T, Gray JW (1986) Cytogenetic analysis using quantitative, high-sensitivity, fluorescence hybridization. Proceedings of the National Academy of Sciences 83: 2934-2938. doi: 10.1073/pnas.83.9.2934

Pinna MC (1998) Phylogenetic relationships of neotropical siluriforms (Teleostei: Ostariophysi): historical overview and synthesis of hypotheses. In: Malabarba LR, Vari RE, Lucena ZM, Lucena CA (Eds) Phylogeny and Classification of Neotropical Fishes. Edipucrs, Porto Alegre, 279-330.

Stolf R, Swarça AC, Giuliano-Caetano L, Dias AL (2004) Analyses of karyotype and nucleolar organizer regions of Imparfinis aff. schubarti (Siluriformes, Pimelodidae) of the Tibagi river basin, Paraná, Brazil. Caryologia 57: 348-352. doi: 10.1080/00087114.2004.10589415

Sumner AT (1972) A simple technique for demonstrating centromeric heterochromatin. Experimental Cell Research 75: 304-306. doi: 10.1016/0014-4827(72)90558-7

Suzuki H, Moriwaki K, Sakurai S (1994) Sequences and evolutionary analysis of mouse $5 \mathrm{~S} \mathrm{r}$ DNAs. Molecular Biology and Evolution 11: 704-710.

Swarça AC, Fenocchio AS, Dias AL (2007) An update Cytogenetic Review for Species of the Families Pseudopimelodidae, Pimelodidae and Heptapteridae (Pisces, Siluriformes). Sugestion of a Cytotaxonomical Classification. Caryologia 60: 334-348. doi: 10.1080/00087114.2007.10797957

Swarça AC, Vidotto AP, Dias AL (2003) Cytogenetic characterization of Pimelodella aff. avanhandavae (Siluriformes, Pimelodidae) from Tibagi River (Paraná State, Brazil). Caryologia 56: 421-425. doi: 10.1080/00087114.2007.10797957

Tsuda JR, de Moraes VPO, Giuliano-Caetano L, Dias AL (2010) Occurrence of natural triploidy in Rhamdia quelen (Siluriformes, Heptapteridae). Genetics and Molecular Research 9: 1929-1935. doi: 10.4238/vol9-3gmr949 
Vasconcelos C, Martins-Santos IC (2000) Chromosome polymorphism in species of the Pimelodidae family (Pisce, Siluriformes). Hereditas 132: 103-109. doi: 10.1111/j.16015223.2000.00103.x

Vidotto AP, Swarça AC, Fenocchio AS, Dias AL (2004) Cytogenetic studies in three Pimelodella meeki populations (Pisces, Pimelodidae) from Tibagi River Basin (Brazil). Journal of Heredity 95: 517-520. doi: 10.1093/jhered/esh075

Vissoto PC, Foresti F, Oliveira C (1999) Karyotype description of five species of Pimelodidae (Teleostei, Siluriformes). Chromosome Science 3: 1-7.

Vissotto PC, Foresti F, Oliveira C (2001) Karyotypic characterization of two species of the genus Imparfinis (Teleostei, Siluriformes, Heptapteridae). Chromosome Science 5: 97-103.

Yano CF, Margarido VP (2012) First cytogenetic studies of the genus Heptapterus (Actinopterygii, Siluriformes): karyotype differentiation and review of cytogenetic data on the Heptapteridae family. Journal of Fish Biology 81: 939-953. doi: 10.1111/j.1095-8649.2012.03314.x

Wasko AP, Martins C, Wrigth JM, Galetti Jr PM (2001) Molecular organization of 5S rDNA in fishes of the genus Brycon. Genome 44: 893-902. doi: 10.1139/gen-44-5-893

Williams SM, Strobeck C (1985) Sister chromatid exchange and the evolution of rDNA spacer length. Journal of Theoretical Biology 116: 625-636. doi: 10.1016/S00225193(85)80092-8

Zanke C, Borisjuk N, Ruoss B, Schilderentschler L (1995) A specific oligonucleotide of the 5 S rDNA spacer anda species-specific elements identify symmetrical somatic hybrids between Solanum tuberosum and S. pinnatisecum. Theoretical and Applied Genetics 90: 720-726. doi: $10.1007 / \mathrm{BF} 00222139$ 